\title{
Defects in the Surface Layer of Pure Molybdenum after WEDM
}

Katerina Mouralova ${ }^{1}$, Libor Benes ${ }^{2}$, Radim Zahradnicek ${ }^{3}$

${ }^{1}$ Faculty of Mechanical Engineering, Brno University of Technology. Technicka 2896/2, 61669 Brno. Czech Republic. E-mail: mouralova@fme.vutbr.cz

${ }^{2}$ Faculty of Mechanical Engineering, J. E. Purkyne University in Usti nad Labem. Pasteurova 3334/7, 40001 Usti nad Labem. Czech Republic. E-mail: libor.benes@ujep.cz

${ }^{3}$ Faculty of Electrical Engineering and Communication, Brno University of Technology. Technicka 3058/10, 616 00 Brno. Czech Republic. E-mail: zahradnicek@vutbr.cz

The utilisation of pure molybdenum in high-temperature applications in a vacuum requires very precise machining. Considering the fact that conventional machining methods do not achieve the required geometrical and dimensional accuracy in several cases, it is necessary to use the unconventional technology of wire electrical discharge machining (WEDM). This study aims at analysing the surface and subsurface layer of pure molybdenum after WEDM in terms of the occurrence of defects. Profile and areal parameters were evaluated by means of a contact 3D profilometer. The occurrence of individual defects both on the surface and underneath it was studied by means of the methods of electron microscopy and focused ion beam (FIB). Furthermore, the local chemical composition of the surface of the workpiece (EDX) was determined.

Keywords: WEDM, Electrical Discharge Machining, pure molybdenum, morphology of surface, topography, chemical composition, cracks

\section{Acknowledgement}

This work was supported by the Ministry of Education, Youth and Sport of the Czech Republic, the program NPU1, project No. LO1207.

The article was supported by project no. FEKT-S-17-3934, Utilization of novel findings in micro and nanotechnologies for complex electronic circuits and sensor applications.

This research has been financially supported by the Ministry of Education, Youth and Sports of the Czech Republic under the project CEITEC 2020 (LQ1601).

\section{References}

[1] HO, K. H., NEWMAN, S. T., RAHIMIFARD, S., \& ALLEN, R. D. (2004). State of the art in wire electrical discharge machining (WEDM). In: International Journal of Machine Tools and Manufacture, pp. 1247-1259.

[2] JAMESON, E. C. (2001). Electrical discharge machining. Society of Manufacturing Engineers. ISBN 0-87263521-X.

[3] MOURALOVÁ, K.; BEDNÁř, J.; KOVÁŘ, J.; MACH, J. (2016). Evaluation of MRR after WEDM depending on the resulting surface. In: Manufacturing TECHNOLOGY, pp. 396-401.

[4] BLECHA, P. (2006). Integration of risk management into Meta- Quality Deployment method. In AEDS 2006 Workshop Proceedings. Plzeň: Západočeská univerzita v Plzni, pp. 23.

[5] LIAO, Y. S., CHEN, S. T., \& LIN, C. S. (2004). Development of a high precision tabletop versatile CNC wireEDM for making intricate micro parts. Journal of Micromechanics and Microengineering, 15(2), 245.

[6] SIVAPRAKASAM, P., HARIHARAN, P., \& GOWRI, S. (2014). Modeling and analysis of micro-WEDM process of titanium alloy (Ti-6Al-4V) using response surface approach. Engineering Science and Technology, an International Journal, 17(4), pp. 227-235.

[7] PRASAD, D. S., SHOBA, C., VARMA, K. R., \& KHURSHID, A. (2015). Influence of wire EDM parameters on the damping behaviour of A356. 2 aluminum alloy. Journal of Alloys and Compounds, 646, pp. 257-263.

[8] RAO, P. S., RAMJ, K., \& SATYANARAYANA, B. (2014). Experimental investigation and optimization of wire EDM parameters for surface roughness, MRR and white layer in machining of aluminium alloy. Procedia Materials Science, 5, pp. 2197-2206.

[9] REDDY, V. C., DEEPTHI, N., \& JAYAKRISHNA, N. (2015). Multiple response optimization of wire EDM on aluminium HE30 by using grey relational analysis. Materials Today: Proceedings, 2(4-5), 2548-2554. 
[10] BOBBILI, R., MADHU, V., \& GOGIA, A. K. (2015). Multi response optimization of wire-EDM process parameters of ballistic grade aluminium alloy. Engineering Science and Technology, an International Journal, 18(4), pp. $720-726$.

[11] JIANG, X. J., WHITEHOUSE, D. J. (2012). Technological shifts in surface metrology. CIRP Annals-Manufacturing Technology, 61(2), pp. 815-836.

[12] WAIKAR, R. A., GUO, Y. B. (2008). A comprehensive characterization of 3D surface topography induced by hard turning versus grinding. Journal of materials processing technology, 197(1), pp.189-199.

[13] HARČARÍK, M., JANKOVÝCH, R. (2016). Relationship between values of profile and areal surface texture parametres. MM Science Journal, 2016, 5, pp. 1659-1662.

[14] Geometrical Product Specifications (GPS) -Surface texture: Areal-Part 2: Terms, definitions and surface texture parameters. ISO 25178-2 (2012). Geneva: International Organization for Standardization.

[15] Geometrical Product Specifications (GPS) -Surface texture: Profile method -Terms, definitions and surface texture parameters. ISO 4287 (1997). Geneva: International Organization for Standardization.

[16] MOURALOVÁ, K., BENEŠ, L., ZAHRADNÍČEK, R. (2016). Study of surface morphology and topography of pure iron machined by WEDM. Manufacturing TECHNOLOGY, 5,pp. 1051-1055.

[17] MOURALOVÁ, K., ZAHRADNÍČEK, R., HRDÝ, R. (2016). Occurrence of globule of debris on surfaces machined by WEDM. MM Science Journal, 6, pp. 1630-1633.

[18] SHARMA, P., CHAKRADHAR, D., \& NARENDRANATH, S. (2015). Evaluation of WEDM performance characteristics of Inconel 706 for turbine disk application. Materials \& Design, 88, pp. 558-566.

[19] MANJAIAH, M., NARENDRANATH, S., BASAVARAJAPPA, S., \& GAITONDE, V. N. (2015). Investigation on material removal rate, surface and subsurface characteristics in wire electro discharge machining of Ti50Ni50-xCux shape memory alloy. Proceedings of the Institution of Mechanical Engineers, Part L: Journal of Materials: Design and Applications.

[20] KUMAR, A., KUMAR, V., \& KUMAR, J. (2013). Experimental Investigation on material transfer mechanism in WEDM of pure titanium (Grade-2). Advances in Materials Science and Engineering.

[21] MCGEOUGH, J. A. (1988). Advanced methods of machining. Springer Science \& Business Media.ISBN 9780412319709. 